\title{
Empirical Research of the Relationship among Customer Satisfaction, Customer Loyalty and Business Performance in Banking Sector
}

\section{- Illustrated by Bank of China}

\author{
Xin xin $^{1}$, Liu Wen-chao ${ }^{2}$, Bao Hong-li ${ }^{3}$ \\ ${ }^{1}$ Department of Business Administration Jilin Business and Technology College, Changchun Jilin province, China \\ ${ }^{2}$ Department of Business Administration Jilin University of Finance and Economics, Changchun Jilin province, China \\ 3 Department of marketing China Mobile of Tongliao branch, Tongliao, Neimenggu provice, China \\ xinxin9826@126.com, liuwenchao211@163.com, 409694332@qq.com
}

\begin{abstract}
Competition is increasing in Chinese banking industry and gaining more customer satisfaction has become the focus of competition. Through empirical research, we found: CS has positive effect on customer loyalty in Chinese banking industry; CS has positive effect on bank's business performance and some dimensions; CL has positive effect on bank's business performance and some dimensions; CL has partial intermediary role in the influence of CS on the performance of banks and some dimensions.

Index Terms - Customer satisfaction, Customer loyalty, Business performance, Banking
\end{abstract}

\section{Introduction}

With the deepening of open to the outside world for the Chinese financial market, foreign banks to enter China fall over each other. According to statistics, by the end of 2012, the total number of business institutions of foreign bank in China have reached 412, resulting in China's commercial banks are facing more and more intense competition. At the same time, Chinese customers are more unsatisfied with the local commercial banks. According to the China CS survey results of 2014 year, four of $\mathrm{t}$ he five big state-owned banks' satisfaction results are below the average line [1]. How to make Chinese commercial banks survive and develop in the competition is become the focus of the academic circles and concerns of the banks in recent years. Understanding of CS with the banks' products and services are very important. It helps our commercial banks to grasp the direction of improvement and innovation. Some experts point out that the banking industry has some bad habits such as "official" and "business", which lead the banks could not treat users equally. And the banks also excessive emphasis on money and set all kinds of unreasonable fees and rates for customers. So the banking industry must start to change and set up the "customers first" principle. From the theory of service profit chain, the key for the banking industry is to win CS. As we know, only satisfied customers will become loyal customers, and may produce the continued behaviour. It will bring profits and achieve sustainable development for the bank. On the contrary, the customers who are not satisfied or frustrated with the products or services, though may keep silent, but would have the opportunity to choose another bank. Therefore, let more CS has become the focus of competition among banks. At present, although some domestic scholars noted that the correlation among customer value, CS, $\mathrm{CL}$ and service quality, but few scholars do empirical research on the relationship among CS, CL and business performance of the banking industry. This paper selects bank of China as the research object, to empirical study the relationship among $\mathrm{CS}, \mathrm{CL}$ and corporate performance in China's specific situation and characteristics of the industry.

\section{Theoretical Framework and Research Hypothesis}

\subsection{Theoretical Framework}

Customer satisfaction (CS) is a mature concept in the field of marketing. Scholars generally believe that CS is a kind of attitude that customer like or didn't like arising after the consumption. CS can lead to more customers repeat purchase or add to buy other commodities [2]. CL is emphasized a preference attitude. Customers like to buy the same brand for long-term under the preference of the products and services [3]. CL isn't only about behaviour, also reflected in the customer preferences, interests and future purchase intention. $\mathrm{CL}$ is a kind of behaviour combined with consciousness. And it is a kind of continuous purchase intention or commitment made by customers who felt satisfied with the products or services. Business performance is usually used to measure enterprise efficiency and effectiveness. CS can bring CL, and CL related to business profit directly (Zheng Qiuying et al., 2014) [4].

According to these theories, and combined with China's banking industry, we put forward the theoretical framework (Figure 1). The model consists of three parts, independent variable is CS, CL is intermediary variable, and dependent variable is business performance. According to the 2006 SASAC issued revised "rules for the implementation of comprehensive performance evaluation of central enterprises", business performance of Chinese banks are specific into four indexes: performance in profitability, operation ability, development ability and the debt paying ability [5]. 


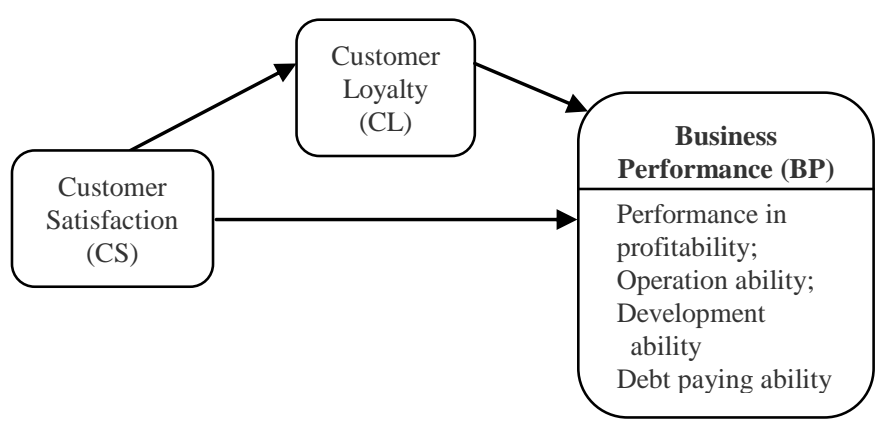

Fig.1 Theoretical framework

\subsection{Research Hypothesis}

(1) Analysis of the relationship between CS and CL

At present, most of the scholars and businessmen believe that CS should be related to the CL in theory. The improvement of CS will lead to repeat purchase, cross buying and positive word-of-mouth behaviours, and satisfied customers are more willing to recommend enterprise products and services to their friends and relatives. Therefore, highly satisfied customers will have a higher loyalty to the enterprise, but also in the banking industry. E Mubarak Ali et al (2011) pointed that the "quality service" is the key to win in the competition in the banking sector, and through CS it can improve CL to the bank [6]. Titko \& Lace (2011) thought, once a customer satisfied with a bank usually is not easy to transfer, and it helps to maintain CL [7].

Po-Young CHU (2012) research showed that customers' trust and satisfaction have positive effect on CL on electronic banking [8]. In order to verify the theory's suitability for China's banking industry, we put forward the hypothesis

H1: CS has positive effect on CL in Chinese banking industry.

(2) Analysis of the relationship between CS and business performance

CS have a positive relation with indicators that measure corporate performance, such as turnover, market share, shareholder value, cash flow, stock price. Hallowell (1996) showed that CS lead to CL in banking and CL leads to enterprise profitability growth [9]. Specifically, a satisfied customer will purchase a product or service repeatedly, and lead to a direct result of corporate sales rise. Satisfied customers easy to accept the product or service premium based on the trust. At the same time, satisfied customers will help to establish a good reputation for enterprises, and so as to save the enterprise marketing and promotion expenses. In addition, CS will reduce recovery cost of marketing failure. Sales increase and decrease in marketing costs will bring increase of enterprise profit. When the customers satisfied, they will buy other products or services provided by the enterprise. This would reduce the difficulty for enterprise new products or services entering into the market. It would also accelerate the enterprise cash flow and enhance the enterprise short-term debt paying. In addition, along with the increase of profit, enterprise long-term debt paying ability improved. Therefore, the degree of CS would affect ability of debt paying for the enterprise. Vikas \& Wagner (2001) showed that a satisfied customer will maintain good interactive relationship with the enterprise, and brings the enterprise asset turnover rate through the learning curve effect. So CS will enhance the enterprise operation ability [10]. In the service industry, CS is related with the operating capacity and the efficiency. The growth of enterprises depends on technological innovation, personnel training and so on. These factors need financial support. Enterprise funds mainly come from the profits of enterprises. Therefore, the profitability of enterprises determines the enterprise growth ability. Based on the analysis, we put forward the hypothesis:

H2: CS has a positive impact on BP in banking industry.

H2a: CS has a positive impact on the profitability of the business in the banking industry.

H2b: CS has a positive impact on enterprise debt paying ability in the banking industry.

H2c: CS has a positive impact on the operating capacity in the banking industry.

H2d: CS has a positive effect on growth ability of enterprise in the banking industry.

(3) Analysis of the relationship between CL and business performance

At present, the researchers and the practisers are generally recognized CL is related to enterprise profit directly. Firstly, loyalty customers are exhibit low sensitivity to the enterprise product or service premium, and often able to accept a product or service at a higher price. Secondly, the loyal customers are often long-term customers, can shorten the Business Hours, convenient service process, and reduce the cost of enterprises. Thirdly, loyal customers are easy to accept the new products of the enterprise, and also are willing to achieve cross purchase, so as to reduce the difficulty and cost of new products into the market, and increase enterprise sales revenue. Fourth, loyal customers are more willing to recommend the enterprise products to friends and family, resulting in increased customer referral value. Of course, there is also a lot of value with CL, so that some scholars put forward, the loyal customer is the profit source of enterprise [11]. CL degree is the determinant of bank's business efficiency and competitive advantage. Anderson (2004) study showed that CL is the most important driving force for the bank to improve the financial performance [12]. The competition of banking industry is becoming increasingly fierce. Customer loyalties play a more decisive role to the bank's profit. CL is the basic source of customer assets for the bank, and it is the most stable and valuable intangible assets for the bank. We put forward the hypothesis:

H3: CL has a positive impact on BP in the banking industry.

H3a: CL has a positive impact on the operating capacity in the banking industry.

H3b: CL has a positive impact on the profitability of the business in the banking industry.

H3c: CL has a positive impact on $t$ enterprise debt paying ability in the banking industry. 
H3d: CL has a positive impact on growth ability of enterprise in the banking industry.

(4) Analysis of the relationship among CS, CL and business performance

As already pointed out, CS is the primary condition to obtain the customer resources. Because satisfaction can bring the loyalty and the loyal customer is the source of enterprise profit stability. From the service profit chain theory, CL plays a mediating role in the $\mathrm{CS}$ and business performance. In China, some scholars had taken the hotel industry, telecommunication industry and pharmacy industry as the research background, and they found CS has a significant positive correlation with $\mathrm{CL}$. And $\mathrm{CL}$ is a significant intermediary role in the positive relationship between CS and business performance. Gritti \& Foss (2010) took the Bank of Italy as an example and the study found CS directly affect CL, and then affect financial and non-financial customer value, namely the total customer value. In addition, the CL has mediating effect between in the total customer value and customer sources [13]. Therefore, we put forward the hypothesis:

H4: CL plays an intermediary role in the relationship between CS and $B P$ in the banking industry.

H4a: CL plays an intermediary role between CS and enterprise's profit ability in the banking industry.

H4b: CL plays an intermediary role between CS and enterprise operation ability in the banking industry.

H4c: CL plays an intermediary role between CS and enterprise debt paying ability in the banking industry.

H4d: CL plays an intermediary role between CS and enterprise growth ability in banking industry.

\section{Variable Measurement and Data Sources}

\subsection{Variable Measurement}

CS measurement comes from China CS index (CSI) model which is proposed by Professor Zhao Ping of Tsinghua University (1995) [14]. CL measurement mainly referred from Morgan (2006) [15], and measured from three aspects: the repurchase intention or behaviour, establish the reputation and accept a premium. BP measurement was based on the revised edition of "SASAC central enterprise performance evaluation rules" which issued in 2006. Business performance $=$ net assets yield * 0.34+ net profit growth rate of $* 0.22+$ assets and liabilities rate $* 0.22+$ total assets turnover rate $* 0.22$.

\subsection{Data Sources}

This paper selects and analyse the CS and CL index from 2003 to 2012 in the "handbook of CS in China". We got the special data from official website of the bank of China, listing Corporation annual report, authoritative database of Guotai Junan. We access net profit of nearly ten years of growth, asset liability ratio, rate of return on net assets and total assets turnover and other financial indicators of the bank of China. These data can measure the enterprise's development ability, debt paying ability, operating ability and profit ability. We do the correlation and regression analysis by the use of SPSS19.0.

\section{Data Analysis and Hypothesis Testing}

\subsection{Correlation analysis}

Correlation analysis was performed on the variables and results shown in table 1 . CS is positively related to CL, $\mathrm{r}=0.825$ and significant at .01 level. CS is positive correlation with BP, $\mathrm{r}=0.658$ and significant at 0.05 level. We can also see the relationship between CS and four dimensions of BP: CS is positive correlation with NAY, AIR and GRNP, but not significant correlation with TTC. CL is positively related to $\mathrm{BP}, \mathrm{r}=0.536$ and significant at 0.05 level. We can also see the relationship between CL and four dimensions of BP: $\mathrm{CL}$ is positive correlation with NAY and AIR, but not significant correlation with TTC and GRNP.

TABLE 1 The Results of Correlation Analysis

\begin{tabular}{|c|c|c|c|c|c|c|c|}
\hline & AIR & NAY & TTC & GRNP & BP & CS & CL \\
\hline AIR & 1 & $-.730^{*}$ & -.553 & $-.720^{*}$ & $-.834^{* *}$ & $-.875^{* *}$ & $-.654^{*}$ \\
\hline NAY & $-.73^{*}$ & 1 & .270 & .478 & .410 & $.746^{*}$ & $.774^{* *}$ \\
\hline TTC & -.55 & .270 & 1 & .625 & $.709^{*}$ & .208 & .019 \\
\hline GRNP & $-.72^{*}$ & .478 & .625 & 1 & $.800^{* *}$ & $.679^{*}$ & .482 \\
\hline BP & $-.83^{* *}$ & .410 & $.709^{*}$ & $.800^{* *}$ & 1 & $.658^{*}$ & $.536^{*}$ \\
\hline CS & $-.87^{* *}$ & $.746^{*}$ & .208 & $.679^{*}$ & $.658^{*}$ & 1 & $.825^{* *}$ \\
\hline CL & $-.65^{*}$ & $.774^{* *}$ & .019 & .482 & $.536^{*}$ & $.825^{* *}$ & 1 \\
\hline
\end{tabular}

*. Significant at $0.05 ; * *$. Significant at 0.01

AIR- asset-liability ratio; NAY- net assets yield; TTC- turnover of total capital; GRNP- growth rate of net profit; BP- Business performance; CSCustomer satisfaction; CL- Customer loyalty

\subsection{Regression Analysis}

(1) Bivariate Regression Analysis

Through regression analysis, the influence from CS on $\mathrm{CL}$ and $\mathrm{BP}$ and $\mathrm{CL}$ on performance, in table 2:

First, we see the analysis of the impact of CS on CL from table 2. $\mathrm{F}=17.093$, $\mathrm{p}=0.000$, adjusted $\mathrm{R}$ is 0.681 , that means a significant positive effect of CS on CL, H1 was supported.

Secondly, we see the analysis of the impact of CS on business performance. The adjusted $\mathrm{R}$ value is $0.659, \mathrm{~F}$ $=18.367, \mathrm{p}=0.03$, that means CS has a significant positive effect on business performance, $\mathrm{H} 2$ was supported. When we see the analysis of the impact of CS on TTC, F=3.450, $\mathrm{p}=0.100$, more than 0.05 , the regression results is not significant, so $\mathrm{H} 2 \mathrm{a}$ was not supported. When we see the analysis of the impact of CS on NAY, F=55.065, p=0.000, adjusted $\mathrm{R}$ value is $0.837, \mathrm{H} 2 \mathrm{~b}$ was supported. When we see the analysis of the impact of CS on GRNP, $\mathrm{F}=6.851, \mathrm{p}=0.031$, adjusted $\mathrm{R}$ value is $0.394, \mathrm{H} 2 \mathrm{c}$ was supported. When we see the analysis of the impact of CS on AIR, $\mathrm{F}=26.242$, $\mathrm{p}=0.001$, $\mathrm{H} 2 \mathrm{~d}$ was supported.

Next, we see the analysis of the impact of CL on business performance. We see the impact of CL on business performance, adjusted $\mathrm{R}$ value is $0.4, \mathrm{~F}=18.367, \mathrm{p}=0.029, \mathrm{H} 3$ was supported. We see the impact of CL on TTC, and H3a was not supported. We see the impact of CL on NAY, and $\mathrm{H} 3 \mathrm{~b}$ was supported. We see the impact of CL on GRNP, and H3c was not supported. We see the impact of CL on AIR, and H3d was supported. 
TABLE 2 Results of Bivariate Regression Analysis

\begin{tabular}{|c|c|c|c|c|c|c|c|c|}
\hline ID & $\mathbf{D}$ & $\boldsymbol{\beta}$ & $\mathbf{S .} \boldsymbol{\beta}$ & $\mathbf{T}$ & $\mathbf{R}^{\mathbf{2}}$ & $\mathbf{A . ~ \mathbf { R } ^ { 2 }}$ & $\mathbf{F}$ & Sig. \\
\hline CS & CL & 1.13 & .825 & 4.134 & .681 & .641 & 17.09 & .000 \\
\hline CS & BP & 12.39 & .880 & 5.239 & .697 & .659 & 18.36 & .003 \\
\hline CS & TTC & .097 & .208 & .600 & .301 & .214 & 3.450 & .100 \\
\hline CS & NAY & .385 & .934 & 7.421 & .873 & .857 & 55.06 & .000 \\
\hline CS & GRNP & 12.55 & .679 & 2.618 & .461 & .394 & 6.851 & .031 \\
\hline CS & AIR & -.375 & -.875 & -5.123 & .766 & .737 & 26.24 & .001 \\
\hline CL & BP & 9.31 & .683 & 2.645 & .466 & .400 & 6.994 & .029 \\
\hline CL & TTC & .006 & .019 & .053 & .000 & -.125 & .003 & .959 \\
\hline CL & NAY & 2.64 & .751 & 3.221 & .565 & .510 & 10.37 & .012 \\
\hline CL & GRNP & 7.83 & .582 & 2.023 & .338 & .256 & 4.092 & .078 \\
\hline CL & AIR & -.281 & -.861 & -4.788 & .741 & .709 & 22.92 & .001 \\
\hline
\end{tabular}

Notes: ID-independent variable; D-dependent variable; CS- Customer satisfaction; CL- Customer loyalty; BP- Business performance; AIR- assetliability ratio; NAY- net assets yield; TTC- turnover of total capital; GRNP- growth rate of net profit

\section{(2)Multiple Regression Analysis}

Using regression analysis to test the influences of CS and $\mathrm{CL}$ on BP and its dimensions, results shown in table 3. CL mediated in CS and BP. Regression coefficient of CS on BP from 0.880 to 0.280 (Table 3 and table 2 comparison), the coefficient dropped significantly. This shows that the effect of CS on BP is achieved through CL partly. Therefore, CL plays a partial mediating role in the relationship between CS and $\mathrm{BP}$, and $\mathrm{H} 4$ was supported.

TABLE 3 Results of Multiple Regression Analysis

\begin{tabular}{|c|c|c|c|c|c|c|}
\hline \multirow{2}{*}{ IID } & \multirow{2}{*}{$\mathrm{D}$} & \multicolumn{2}{|c|}{ Non-stand coefficient } & \multirow[t]{2}{*}{ Stand- coef } & \multirow{2}{*}{$\mathrm{t}$} & \multirow{2}{*}{ Sig. } \\
\hline & & B & S.E. & & & \\
\hline \multirow{2}{*}{$\begin{array}{l}\text { CS } \\
\text { CL }\end{array}$} & \multirow{2}{*}{ BP } & 4.765 & 8.681 & .280 & .549 & .600 \\
\hline & & 6.085 & 6.949 & .446 & .876 & .410 \\
\hline \multirow{2}{*}{$\begin{array}{l}\mathrm{CS} \\
\mathrm{CL}\end{array}$} & \multirow{2}{*}{ TTC } & .005 & .184 & .015 & .026 & .980 \\
\hline & & .143 & .147 & .564 & .970 & .36 \\
\hline \multirow{2}{*}{$\begin{array}{l}\text { CS } \\
\text { CL }\end{array}$} & \multirow{2}{*}{ NAY } & .397 & 1.71 & .086 & .231 & .824 \\
\hline & & 2.879 & 1.37 & .779 & 2.09 & .074 \\
\hline \multirow{2}{*}{$\begin{array}{l}\mathrm{CS} \\
\mathrm{CL}\end{array}$} & \multirow{2}{*}{ GRNP } & 3.417 & 8.76 & .185 & .39 & .708 \\
\hline & & 8.629 & 7.01 & .583 & 1.23 & .258 \\
\hline \multirow{2}{*}{$\begin{array}{l}\mathrm{CS} \\
\mathrm{CL}\end{array}$} & \multirow{2}{*}{ AIR } & -.291 & .143 & -.680 & -2.04 & .080 \\
\hline & & -.079 & .114 & -.230 & -.69 & .512 \\
\hline
\end{tabular}

Notes: ID-independent variable; D-dependent variable; CS- Customer satisfaction; CL- Customer loyalty; BP- Business performance; AIR- assetliability ratio; NAY- net assets yield; TTC- turnover of total capital; GRNP- growth rate of net profit

Comparing tables 3 and 2, we see the impacts of CS on the four dimensions of BP: When CL was mediated in CS and operational capacity (TTC), the regression coefficients of CS to operating capacity was dropped from 0.28 to 0.015 , the coefficient decreased significantly, H4a was supported. When CL was mediated in CS and profitability (NAY), regression coefficients of CS to profitability was dropped from 0.934 to 0.086 , the coefficient decreased significantly, H4b was supported. When CL was mediated in CS and development ability (GRNP), the regression coefficients of CS to development ability was dropped from 0.679 to 0.185 , the coefficient decreased significantly, $\mathrm{H} 4 \mathrm{c}$ was supported. When CL was mediated in CS and debt paying ability (AIR), the regression coefficients of CS to profitability was dropped from -0.875 to -0.680 , coefficient increased significantly, $\mathrm{H} 4 \mathrm{~d}$ was not supported.

\section{Research Conclusion}

Through the empirical research, we found that CS has obvious positive impact on $\mathrm{CL}$ in Chinese banking industry. It means that in the banking industry, CS is the base of CL. In order to get more loyal customers, banks should strive to make more customers feel satisfaction. There were positive correlation between CS and overall BP and its four dimensions in Chinese banking industry. There were positive correlation between CL and overall BP and its four dimensions in Chinese banking industry. CL was mediated in CS and BP and its four dimensions in Chinese banking industry. In general, in order to obtain higher profits, the bank of China has to a using all available resources and through various efforts to accomplish follows: make the dissatisfied customer become satisfied, make customers feel more satisfaction and develop more loyal customers.

\section{References}

[1] Yu Wanni. Customer dissatisfied with China state-owned banking services. Worker's daily, March 31, 2014.

[2] Cardozo, Richard N. An Experimental Study of Customer Effort, Expectation and Satisfaction. Journal of Marketing Research,1965,2 (August): 244-249

[3] Rust, Roland T., Anthony J. Z. Customer satisfaction, customer retention, and market share. Journal of Retailing, 1993, 69(2):193-215.

[4] Zheng Qiuying et al. study on Influence Factors of "customer satisfaction and customer loyalty" Based on Meta analysis. Management review, 2014(2): 111-120.

[5] The state owned assets supervision and Administration Commission of the State Council. Detailed rules for the implementation of comprehensive performance evaluation for central enterprises. October 27, 2006.

[6] E Mubarak Ali,G S David Sam Jaykumar. Service quality of Indian Bank in Thanjavur District: evidence from survey data. The IPU Journal of Bank Management, 2011, 2:81-89.

[7] TITKO J. and LACE, N.. Customers'and Employees'Perceptions of a Bank Value. The Scientific Journal of Riga Technical University "Economics and Business", 2011, 3 (21):85-90.

[8] Po-Young Chu, Yu Chao. Service quality, customer satisfaction, customer trust, and loyalty in an E-Banking context]. Social Behavior and Personality, 2012, 4 (8):1271-1284.

[9] Roger Hallowell. The relationships of customer satisfaction, customer loyalty, and profitability: an empirical study. IJSIM, 1996, (7):27-42.

[10] Vikas M, Wagner A K. Satisfaction, Repurchase Intent, and Purchase Behavior: Investigating the Moderating Effect of Customer Characteristics. Journal of Marketing Reseach, 2001, 2:131-142.

[11] Berry L.L., Parasuraman A.Marketing Services: Competing through Quality. New York: The Free Press, 1990.

[12] Anderson C F, Mavanchery S. K. Customer satisfaction and shareholder value. Journal of Marketing, 2004, 68 (4):172-185.

[13] Paola Gritti and Nicolai Foss. Customer satisfaction and competencies: an economic study of an Italian bank. Applied Economics Letter, 2010, 17: 1811-1817.

[14] Zhao Ping. Customer satisfaction index (CSI). China Quality, 1995, (12): $37-38$

[15] Neil A Morgan. The value of different customer satisfaction and loyalty metrics in predicting business performance. Marketing Science, 2006, 5 (25):426-439. 